\title{
Studi Kasus Kecurangan Akuntansi pada Koperasi Mitra Jaya Kelurahan Penarukan Kecamatan Buleleng (Suatu Kajian Terhadap Pentagon Crowy)
}

\author{
Riska Larasati ${ }^{*}$, Edy Sujana $^{2}$ \\ ${ }^{123}$ Program Studi S1 Akuntansi, Universitas Pendidikan Ganesha, Singaraja, Indonesia \\ *riskalarasati42@gmail.com
}

\section{Abstrak}

Penelitian ini bertujuan untuk memperoleh bukti empiris tentang kecurangan akuntansi pada Koperasi Mitra Jaya Kelurahan Penarukan Kecamatan Buleleng dari perspektif pressure, opportunity, rasionalisasi, competency, dan arrogance. Penelitian ini merupakan penelitian kualitatif deskriptif. Data yang digunakan dalam penelitian ini adalah data primer dan data sekunder. Hasil penelitian ini menunjukan bahwa: (1) Fraud yang dilakukan oleh Koperasi Mitra Jaya dilihat dari aspek pressure atau tekanan antara lain karena adanya hutang, gaya hidup mewah hingga berhutang yang peruntukannya tidak sesuai dengan perjanjian hutang sehingga terjadi kredit macet yang berdampak pada permodalan koperasi hingga berimbas pada pembagian SHU di akhir tahun. (2) Fraud yang dilakukan oleh Koperasi Mitra Jaya dilihat dari aspek opportunity atau kesempatan antara lain karena didukung oleh situasi dan kondisi yang memungkinkan seseorang bisa berbuat curang atau adanya kesempatan untuk melakukan manipulasi data keuangan maupun data pribadi terkait pengajuan pinjaman. (3) Fraud yang dilakukan oleh Koperasi Mitra Jaya dilihat dari aspek rasionalisasi diantaranya karena sikap pelaku yang mencari alasan untuk membenarkan kejahatan yang telah dilakukannya sehingga dapat diterima oleh masyarakat. (4) Fraud yang dilakukan oleh Koperasi Mitra Jaya dilihat dari aspek competency antara lain karena pelaku memiliki kemampuan untuk mengesampingkan internal kontrol dan mengontrolnya sesuai dengan kedudukan sosialnya guna kepentingan pribadinya. (5) Fraud yang dilakukan oleh Koperasi Mitra Jaya dilihat dari aspek arrogance yang merupakan sikap superioritas dan keserakahan dalam diri seseorang yang menganggap bahwa kebijakan dan prosedur perusahaan sederhananya tidak berlaku secara pribadi sehingga pelaku leluasa melakukan fraud.

Kata Kunci: Fraud, Pressure, Opportunity, Rasionalisasi, Competency, Arrogance

\section{Abstract}

This study aims to obtain empirical evidence about accounting fraud in the Cooperative Mitra Jaya Kelurahan Penarukan Buleleng District from the perspective of pressure, opportunity, rationalization, competency, and arrogance. This research is a descriptive qualitative research. The data used in this study are primary data and secondary data. The results of this study indicate that: (1) Fraud conducted by Mitra Jaya Cooperative can be seen from the aspect of pressure, such as the existence of debt, luxury lifestyle to debt which is not in accordance with the loan agreement, resulting in bad credit that results in cooperative capital to impact on the division of SHU at the end of the year. (2) Fraud conducted by Koperasi Mitra Jaya is seen from the aspect of opportunity, among others, because it is supported by situations and conditions that enable someone to cheat or an opportunity to manipulate financial and personal data related to loan applications. (3) Fraud conducted by Mitra Jaya Cooperative can be seen from the aspect of rationalization, among others because the attitude of the perpetrators who are looking for reasons to justify the crime they have committed so that it can be accepted by the community. (4) Fraud conducted by Mitra Jaya Cooperative is seen from the aspect of competency, among others because the actor has the ability to override internal control and control it in accordance with his social position for his personal interests. (5) Fraud conducted by Mitra Jaya Cooperative is seen from the aspect of arrogance which is an attitude of superiority and greed in a person who considers that company policies and procedures simply do not apply personally so that the perpetrators are free to commit fraud elements.

Keywords: Fraud, Pressure, Opportunity, Rationalization, Competency, Arrogance

\author{
History: \\ Received: 27 Oktober 2020 \\ Revised: 26 Juni 2021 \\ Accepted: 28 Juni 2021 \\ Published: 30 Juni 2021
}

Publisher: Undiksha Press

Licensed: This work is licensed under

a Creative Commons Attribution 3.0 License

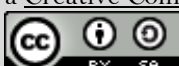




\section{Pendahuluan}

Kecurangan akuntansi (Fraud) bisa terjadi di mana saja dan dapat dilakukan oleh siapa saja meskipun tidak memiliki jabatan. Kecurangan akuntansi adalah salah satu penyebab terjadinya korupsi. Korupsi adalah tindakan seorang pejabat atau petugas yang secara tidak sah dan tidak benar, memanfaatkan pekerjaannya atau karakternya untuk mendapatkan keuntungan bagi dirinya sendiri atau untuk orang lain dengan melangar peraturan dan hak orang lain. Indonesian Corruption Watch (ICW) (2016) menilai bahwa, kasus korupsi di Indonesia saat ini seakan-akan sudah menjadi budaya. Korupsi saat ini sering terjadi di sektor instansi pemerintahan, dari pemerintah pusat sampai pemerintah daerah. Kasus kecurangan baik kecurangan pencatatan maupun pelaporan juga pernah dialami pada beberapa Koperasi di Kecamatan Buleleng. Beberapa tahun yang lalu, bendahara pada Koperasi Mitra Jaya melakukan suatu kecurangan atau fraud. Fraud yang dilakukan yaitu fraud pada pencatatan dan pelaporan. Dimana pegawai dari Koperasi tersebut menggunakan uang kantor untuk kebutuhan pribadinya. Hal itu di ketahui saat Kepala Seksi Pemeriksaan Kelembagaan Koperasi dan KSP/USP. Pada proses pemeriksaan terlihat ada kejanggalan pada anggaran pada tahun 2017. Karena adanya kejanggalan akhirnya Kepala Seksi pemeriksaan melaporkan kejadian tersebut pada Kepala Dinas Koperasi dan UKM Kabupaten Buleleng. Masyarakat sekitar banyak mengetahui hal tersebut sehingga bagi masyarakat kasus fraud tersebut sudah bukan rahasia lagi. Akibat dari tindakan pegawai Koperasi sangat berdampak pada nama Koperasi Mitra Jaya di Kelurahan Penarukan tersebut, banyak masyarakat yang sudah tidak percaya lagi dengan Koperasi Mitra Jaya. Jika masyarakat sudah tidak percaya dengan Koperasi tersebut, maka pemasukan pada Koperasi tersebut akan menurun. Daerah setempat juga akan merasa tercemar karena adanya kasus kecurangan ini. Fraud yang telah terjadi tersebut sangat merugikan banyak pihak yang bersangkutan, baik pihak nasabah, anggota Koperasi dan bahkan Daerah setempat juga akan tercemar.

Fraud merupakan suatu perbuatan dan tindakan yang dilakukan secara sengaja, sadar, tahu dan mau untuk menyalahgunakan segala sesuatu yang dimiliki secara bersama, misalnya: sumber daya perusahaan dan negara demi kenikmatan pribadi dan kemudian menyajikan informasi yang salah untuk menutupi penyalahgunaan tersebut.

Menurut, the Association of Certified Fraud Examiners (ACFE) mengungkapkan bahwa fraud adalah segala upaya untuk mengelabui atau memperdaya pihak lain dengan tujuan untuk memperoleh manfaat pribadi (Priantara dalam Hanifa, 2015). Upaya yang dilakukan pelaku fraud yaitu melakukan perbuatan yang tidak sesuai hukum, penyalahgunaan maupun penyelewengan.

Fraud seperti ulat yang menggerogoti daun tanaman, hingga akhirnya tanaman tersebut layu dan mati. Fraud tidak hanya merusak rantai kepercayaan antara manajemen dan investor namun juga mencederai nilai-nilai dari akuntansi itu sendiri. Salah satu bentuk fraud yang dilakukan adalah memanipulasi informasi laporam keuangan.

Dalam mendeteksi fraud khususnya kecurangan pada laporan keuangan terdapat beberapa cara seperti konsep fraud triangle atau segitiga fraud, berdasarkan riset Donald Cressey (dalam Hanifa, 2015) dan pertama kali diperkenalkan dalam Statment of Auditing Standard (SAS) No. 99 yaitu standar audit di Amerika Serikat yang terdiri dari tekanan, kesempatan dan rasionalisasi.

Tiga sifat umum diatas disebut sebagai faktor risiko fraud. Faktor ini merupakan suatu keadaan yang mengindikasikan tekanan seseorang untuk melakukan penipuan, adanya suatu peluang atau kesempatan untuk melakukan penipuan dan pembenaran individu atas aktifitas yang mengandung fraud. Dalam meningkatkan pendeteksian fraud dapat dilengkapi dengan penggunaan konsep fraud diamond. Konsep ini menambah satu elemen dari fraud triangle yaitu mempertimbangkan kemampuan individu (capability) untuk menjadi orang yang tepat 
melakukan fraud. Menurut Wolfe dan Hermanson (dalam Hanifa, 2015), mengungkapkan bahwa fraud tidak akan terjadi tanpa keberadaan orang yang tepat dengan kemampuan yang tepat. Orang tersebut harus memiliki kemampuan untuk mengenali peluang sebagai sebuah kesempatan dan mengambil keuntungan dari situasi tersebut.

Dalam penelitian ini, peneliti mengambil tiga elemen dari Crowe's fraud pentagon theory, yaitu sebuah teori yang menjelaskan bahwa terdapat lima elemen yang mendasari seseorang melakukan fraud yaitu opportunity, pressure, rationalization, competence, dan arrogance. Elemen yang digunakan dalam penelitian ini adalah arrogance, competence, dan pressure. Teori ini merupakan teori terbarukan hasil pengembangan teori fraud triangle yang dikemukakan oleh Cressey pada 1953. Penelitian sejenis sebelumnya pernah dilakukan oleh Rahmawati (2016) mengenai analisis pengaruh faktor internal dan moralitas manajemen terhadap kecenderungan kecurangan akuntansi: Studi Pada Dinas Pengelola Keuangan dan Aset Daerah Kota Semarang. Penelitian ini dilatarbelakangi oleh keprihatinan terhadap maraknya kasus fraud di Koperasi. Perbedaan penelitian ini dengan penelitian terdahulu terletak pada subjek penelitiannya. Penelitian sebelumnya mengenai fraud masih didominasi oleh model fraud triangle. Masih sedikit penelitian yang dilakukan untuk mengupas kasus ini menggunakan Crowe's fraud pentagon theory. Penelitian ini dilakukan untuk melakukan pengujian lebih mendalam mengenai kemampuan Crowe's fraud pentagon theory yang dikemukakan oleh Crowe (2011) yang mengkhususkan mengambil tiga elemen dari Crowe's fraud pentagon theory yaitu arrogance, competence, dan pressure untuk menginvestigasi dan memberikan penjelasan lebih lanjut apakah Crowe's fraud pentagon theory dapat membantu mendeteksi adanya kecenderungan timbulnya fraud terlebih pada sektor Koperasi di Kelurahan Penarukan.

Berdasarkan latar belakang yang telah diuraikan di atas, maka permasalahan yang akan dibahas dalam penelitian dirumuskan dalam bentuk pertanyaan penelitian yaitu: 1) bagaimana kecurangan akuntansi yang terjadi pada Koperasi Mitra Jaya Kelurahan Penarukan Kecamatan Buleleng dari perspektif pressure, 2) bagaimana kecurangan akuntansi yang terjadi pada Koperasi Mitra Jaya Kelurahan Penarukan Kecamatan Buleleng dari perspektif opportunity, 3) bagaimana kecurangan akuntansi yang terjadi pada Koperasi Mitra Jaya Kelurahan Penarukan Kecamatan Buleleng dari perspektif rasionalisasi, 4) bagaimana kecurangan akuntansi yang terjadi pada Koperasi Mitra Jaya Kelurahan Penarukan Kecamatan Buleleng dari perspektif competency, 5) bagaimana kecurangan akuntansi yang terjadi pada Koperasi Mitra Jaya Kelurahan Penarukan Kecamatan Buleleng dari perspektif arrogance.

\section{Metode}

Penelitian ini menggunakan metode penelitian kualitatif deskriptif. Penelitian kualitatif deskriptif, yaitu penelitian yang memaparkan apa yang terjadi dalam sebuah kancah, lapangan atau wilayah tertentu (Arikunto, 2010). Subjek penelitian ini adalah Koperasi Mitra Jaya yang beralamat di Jalan WR Supratman Singaraja Kelurahan Penarukan Kecamatan Buleleng.

Informan dalam penelitian ini ditentukan secara purposive, yang dimulai dengan informan kunci yang dianggap paling mengetahui permasalahan penelitian. Informan kunci dalam penelitian ini adalah sebagai berikut: pengurus atau pengelola Koperasi Mitra Jaya, pengawas Koperasi Mitra Jaya, dan pihak yang bermasalah dengan Koperasi Mitra Jaya. Obyek penelitian ini adalah kecurangan yang terjadi pada Koperasi Mitra Jaya yang dianalisis dari perspektif Crowe's fraud pentagon theory.

Data primer yang berhubungan dengan penelitian ini adalah data yang diperoleh langsung dari hasil wawancara dengan pihak Koperasi Mitra Jaya Singaraja Kelurahan Penarukan. Data Primer yang dimaksud berupa hasil dari wawancara dengan pihak-pihak 
yang berkaitan dengan Kecurangan Akuntansi yang terjadi pada Koperasi Mitra Jaya Kelurahan Penarukan. Data sekunder dalam penelitian ini diperoleh dari kepustakaan dengan mempelajari literature-literatur, bacaan-bacaan dan buku yang berhubungan dengan permasalahan yang dibahas serta sumber-sumber yang mendukung.

Dalam pengumpulan data, penelitian ini menggunakan tahap pengumpulan data yaitu: survei pendahuluan, studi pustaka, dan survei lapangan. Data yang telah dikumpulkan kemudian diolah melalui tahapan-tahapan sebagai berikut: editing yaitu meneliti kembali data-data yang dikumpulkan untuk mengetahui apakah data-data tersebut sesuai dengan masalah yang penulis bahas, verifikasi yaitu dengan melakukan perbandingan data-data yang diperoleh peneliti dari koperasi yang bersangkutan dengan teori-teori yang ada sebagai landasan. Selanjutnya, akan dilakukan analisis data dengan tujuan untuk menguji hipotesis dalam rangka penarikan kesimpulan.

\section{Hasil dan Pembahasan}

\section{Pelaporan Keuangan dan Akuntansi pada Koperasi Mitra Jaya Kelurahan Penarukan Kecamatan Buleleng}

Dalam hal administrasi khususnya pembukuan akuntansi, Koperasi Mitra Jaya masih mengupayakan mengerjakan dengan selalu berkoordinasi dengan Dinas Koperasi, Perdagangan, dan Perindustrian Kabupaten Buleleng, baik administrasi organisasi/kelembagaan, administrasi usaha dan administrasi keuangan. Begitu pula dengan pengerjaan 14 buku pokok kelembagaan masih diupayakan pengerjaannya.

Permasalahan yang terjadi di Koperasi Mitra Jaya tahun sebelumnya antara lain belum mengadakan Rapat Anggota Tahunan Tahun Buku 2016; adanya dominasi dalam kepengurusan dan pengelolaan koperasi; 16 buku pokok perkoperasian hanya ada sebagian; belum memiliki Anggaran Rumah Tangga (ART), manajemen pengelolaan kurang begitu baik dan tidak adanya kontrol internal yang mengakibatkan koperasi dihadapkan dengan masalah NPL atau kolektibilitas kredit yang cenderung pada posisi ragu-ragu atau macet.

Kasus kecurangan akuntansi yang pernah terjadi di Koperasi Mitra Jaya beberapa tahun yang lalu, dilakukan oleh bendahara. Fraud yang dilakukan yaitu fraud pada pencatatan dan pelaporan. Di mana pelaku menggunakan uang kantor untuk kebutuhan pribadinya. Hal itu di ketahui saat Kepala Seksi Pemeriksaan Kelembagaan Koperasi dan KSP/USP. Pada proses pemeriksaan terlihat ada kejanggalan pada anggaran pada tahun 2017. Karena adanya kejanggalan akhirnya Kepala Seksi pemeriksaan melaporkan kejadian tersebut pada Kepala Dinas Koperasi dan UKM Kabupaten Buleleng.

Masyarakat sekitar banyak mengetahui hal tersebut sehingga bagi masyarakat kasus fraud tersebut sudah bukan rahasia lagi. Akibat dari tindakan oknum bendahara tersebut, nama Koperasi Mitra Jaya di Kelurahan Penarukan menjadi tercoreng dan masyarakat menjadi tidak percaya lagi untuk menyimpan uangnya di Koperasi Mitra Jaya. Jika masyarakat sudah tidak percaya dengan Koperasi tersebut, maka pemasukan pada Koperasi tersebut akan menurun. Daerah setempat juga akan merasa tercemar karena adanya kasus kecurangan ini. Fraud yang telah terjadi tersebut sangat merugikan banyak pihak, baik pengurus koperasi, anggota koperasi maupun lingkungan daerah setempat juga ikut namanya tercemar.

Kecurangan Akuntansi pada Koperasi Mitra Jaya Kelurahan Penarukan Kecamatan Buleleng (Suatu Kajian Terhadap Crowe's Fraud Pentagon Theory)

Banyaknya celah dan kesempatan memperbesar terjadinya kecurangan akuntansi (fraud) pada Koperasi Mitra Jaya Kelurahan Penarukan Kecamatan Buleleng baik oleh pengurus maupun anggota koperasi. Salah satu kasus fraud yang paling besar adalah kasus fraud yang dilakukan oleh oknum bendahara pada Koperasi Mitra Jaya yang melakukan 
manipulasi pada pencatatan dan pelaporan akuntansi pada pembukuan koperasi. Di mana oknum bendahara koperasi tersebut menggunakan uang koperasi untuk kebutuhan pribadinya. Akibat dari tindakan oknum tersebut, Koperasi Mitra Jaya di Kelurahan Penarukan mengalami kerugian baik berupa material maupun non material seperti tercorengnya nama baik koperasi sehingga menurunkan kepercayaan anggota, calon anggota, dan masyarakat. Jika masyarakat sudah tidak percaya dengan koperasi tersebut, maka pemasukan maupun usaha yang dijalankan akan memdapatkan banyak kendala sehingga berakibat pada penurunan modal koperasi. Daerah setempat juga akan merasa tercemar karena adanya kasus kecurangan ini. Fraud yang telah terjadi tersebut sangat merugikan banyak pihak yang bersangkutan, baik pengurus koperasi, anggota koperasi maupun lingkungan daerah setempat juga ikut namanya tercemar.

Fraud lain yang kemungkinan terjadi di Koperasi Mitra Jaya Kelurahan Penarukan Kecamatan Buleleng yang belum bisa dideteksi antara lain penggelapan uang atau barang, kolusi, manipulasi data dan informasi, pencurian barang atau data informasi, gratifikasi, dan mark up biaya.

Penggelapan uang atau barang, bisa terjadi dengan dibarengi manipulasi data dan informasi keuangan pada laporan keuangan Koperasi Mitra Jaya Kelurahan Penarukan Kecamatan Buleleng dengan jumlah yang tidak terlalu signifikan di awal sehingga tidak dapat terdeteksi dengan cepat karena dirasa tidak signifikan. Tetapi, jika dilakukan bertahuntahun jumlah yang di gelapkan jumlahnya menjadi signifikan. Untuk jenis fraud ini yang paling besar kemungkinannya dilakukan oleh pengurus koperasi karena para pengurus tersebut memiliki akses yang lebih besar ke sistem laporan keuangan.

Kolusi juga bisa terjadi untuk dapat menggelapkan uang, atau pun pencurian barang atau data informasi yang penting pada Koperasi Mitra Jaya Kelurahan Penarukan Kecamatan Buleleng ini. Kemungkinan terjadinya kolusi sangatlah tinggi mengingat tidak mungkin oknum tersebut melakukan sendiri tanpa diketahui selama itu oleh pihak yang berwenang dalam hal ini pengawas Koperasi dan juga para anggota koperasi sebagai pemilik bersama koperasi. Modus melakukan kolusi tentunya bisa dilatarbelakangi oleh berbagai alasan, salah satunya adalah karena alasan ekonomi sehingga menghalalkan segala cara untuk mengambil keuntungan dari kesempatan yang ada.

Selain terjadinya kolusi dan penggelapan uang maupun pencurian data dan informasi, kemungkinan fraud yang terjadi pada Koperasi Mitra Jaya Kelurahan Penarukan Kecamatan Buleleng adalah mark up biaya, utamanya dalam pengadaan peralatan penunjang operasional koperasi. Kemungkinan mark up yang dilakukan antara lain: meningkatkan nilai harga (biaya) pembelian dari harga aslinya, menambahkan jumlah unit barang lebih dari yang dibutuhkan, menambahkan anggaran pembelian dalam penganggaran barang dan jasa, pembelanjaan secara terus-menerus di salah satu pemasok, Nota pembelian yang tidak wajar/ meragukan. Hal ini bisa dilakukan oleh para pengurus maupun anggota koperasi dengan melakukan kolusi untuk me-mark up biaya atau belanja operasioanl. Modus yang paling jelas adalah memperoleh keuntungan pribadi.

Selain mark up biaya, kegiatan pelayanan simpanan juga dapat menjadi lahan yang dimanfaatkan untuk melakukan kecurangan dengan melakukan penahanan dan menyalahgunakan uang titipan setoran simpanan/ tabungan untuk kepentingan petugas/pengurus di lapangan, memanipulasi data transkasi, penarikan simpanan/ tabungan secara fiktif oleh kasir atau orang lain, manipulasi data dan informasi data peminjam, suap untuk memperlancar proses peminjaman. Hal ini bisa dilakukan oleh pengurus maupun anggota koperasi dengan melakukan kolusi. Modusnya bisa karena kesulitan keuangan maupun untuk memenuhi gaya hidup yang tidak sejalan dengan pendapatan.

Kemungkinan terjadinya fraud di Koperasi Mitra Jaya Kelurahan Penarukan Kecamatan Buleleng adalah gratifikasi yaitu pemberian sesuatu kepada Petugas/Pengurus 
atas pelayanan pinjaman yang diterima seseorang anggota. Meminjam nama anggota lain untuk memperoleh pinjaman oleh Petugas/ Pengurus/ Pengawas/ Anggota Menahan sementara dan menyalah gunaan uang setoran anggsuran dan bunga pinjaman.

Kemungkinan terjadinya fraud lainnya di Koperasi Mitra Jaya Kelurahan Penarukan Kecamatan Buleleng adalah Penjualan Aset. Penjualan asset dengan harga di bawah harga pasar. Menahan sebagian hasil penjualan aset untuk kepentingan pribadi. Melakukan penjualan aset tanpa melalui proses lelang

Kemungkinan terjadinya fraud di Koperasi Mitra Jaya Kelurahan Penarukan Kecamatan Buleleng lainnya adalah window dressing yaitu dengan manipulasi data dan informasi, penyalah gunaan aset koperasi, pengunaan kendaraan, peralatan, barang milik koperasi untuk kepentingan pribadi, memiliki secara pribadi barang hadiah untuk koperasi dari pihak ketiga, membebankan kepentingan pribadi kepada koperasi (di luar kebijakan yang telah diatur).

Selain beberapa kemungkinan fraud yang bisa terjadi di Koperasi Simpan Pinjam Mitra Jaya Kelurahan Penarukan, Kecamatan Buleleng yang telah dipaparkan di atas, fraud yang mengarah ketindak pidana dapat terjadi seperti adanya anggota fiktif yang hanya mendaftarkan KTP-nya saja dan tidak menyetor seluruh simpanan yang diwajibkan. Atau dengan kata lain, KTP tersebut hanya formalitas dibalik pemodal utama yang merupakan aktor di belakang layar yang mengendalikan koperasi. Koperasi Simpan Pinjam juga banyak ditengarai melakukan praktek perbankan yang jelas-jelas melanggar Pasal 1 ayat 2 UndangUndang Republik Indonesia No. 10 Tahun 1998 yang menerangkan bahwa hanya institusi perbankan yang diperbolehkan untuk menyimpan dana pihak ketiga dan menyalurkan kredit ke masyarakat. Modus Koperasi Simpan Pinjam yang menyimpan dana bukan dari anggota dan juga menyalurkannya ke bukan anggota, jelas-jelas melanggar Undang-Undang Perbankan dan Peraturan Pemerintah Nomor 9 Tahun 1995 yang mana dalam Pasal 18 ayat 2 menyatakan bahwa calon anggota, dalam waktu paling lama 3 (tiga) bulan setelah melunasi simpanan pokok harus menjadi anggota koperasi tersebut (Kurniawan, 2013)

Dari penjelasan di atas, tampak bahwa banyak kemungkinan terjadinya fraud yang bisa terjadi di Koperasi Mitra Jaya Kelurahan Penarukan Kecamatan Buleleng mengingat kondisi koperasi yang banyak celah diantaranya dalam hal pembukuan sehingga Rapat Anggota Tahunan terkendala dalam penyusunan buku laporan pertanggungjawaban.

Terjadinya fraud biasanya baru ketahuan setelah beberapa lama, dan akibatnya sangat berpengaruh jelek terhadap citra lembaga. Dan tidak mudah untuk mendeteksi terjadinya fraud. Yang jelas akan membutuhkan energi pemikiran dan biaya yang banyak untuk menyelesaikan, dan terkadang bersifat rumit. Akibatnya akan timbul kerugian finansial lembaga dan menurunnya tingkat kepercayaan terhadap lembaga.

Tindak kecurangan atau sering disebut dengan fraud bisa terjadi kapan, di mana saja serta oleh siapa saja tidak terkecuali di Koperasi Mitra Jaya Kelurahan Penarukan Kecamatan Buleleng. Modus maupun faktor pendorong melakukan kecurangan (fraud) dapat beraneka ragam, mulai dari kondisi ekonomi, gaya hidup yang tidak disesuaikan dengan kemampuan, karena terlilit hutang dan tidak mampu melunasinya. Modus yang paling berbahaya adalah modus karena memang sudah menjadi hobi untuk melakukan kecurangan di mana saja. Hal ini terkait dengan kesehatan psikologi dan kejiwaan oknum tersebut.

Terdapat beberapa faktor yang mendorong terjadinya fraud antara lain karena adanya kesempatan, tekanan seperti tekanan ekonomi, kemampuan individu untuk melakukan fraud, dan sebagaimanya. Faktor-faktor tersebut dapat dikaji dengan menggunakan Crowe's fraud pentagon theory yang dikemukakan oleh Crowe Howarth pada 2011. Adapun komponen dari Crowe's fraud pentagon theory antara lain: Pressure, Opportunity, Rasionalisasi, Capability/Competency, dan Arrogance. 
Dari hasil analisis tersebut dapat dirangkum Fraud Risk Assesment (FRA) yang terjadi Koperasi Mitra Jaya Kelurahan Penarukan Kecamatan Buleleng, yang dijelaskan pada tabel 4.3 berikut.

Tabel 4.3 Fraud Risk Assesment (FRA) yang terjadi Koperasi Mitra Jaya Kelurahan Penarukan Kecamatan Buleleng.

\begin{tabular}{|c|c|c|c|}
\hline No & Siklus & Proses & Risiko \\
\hline \multirow{3}{*}{1} & \multirow{3}{*}{$\begin{array}{l}\text { Siklus } \\
\text { simpan } \\
\text { pinjam } \\
\text { pada } \\
\text { Koperasi } \\
\text { Mitra Jaya }\end{array}$} & $\begin{array}{l}\text { Proses pengajuan } \\
\text { peminjaman pada } \\
\text { Koperasi Mitra Jaya }\end{array}$ & $\begin{array}{l}\text { a. Risiko pemberian bunga kredit dan plafond yang tidak sesuai } \\
\text { ketentuan, serta risiko terjadinya piutang fiktif. } \\
\text { b. Risiko pembuatan cek secara bulk untuk beberapa transaksi } \\
\text { sehingga sulit untuk ditelusuri. } \\
\text { c. Risiko pelaporan yang tidak handal karena data terkumpul } \\
\text { dulu baru dibuatkan laporan keuangan (sistem batch) }\end{array}$ \\
\hline & & $\begin{array}{l}\text { Proses permintaan } \\
\text { request potong pada } \\
\text { Koperasi Mitra Jaya }\end{array}$ & $\begin{array}{l}\text { a. Risiko kesalahan perhitungan dan pemotongan baik kurang } \\
\text { maupun kelebihan. }\end{array}$ \\
\hline & & $\begin{array}{lr}\text { Proses } & \text { pelunasan } \\
\text { pinjaman } & \text { pada } \\
\text { Koperasi } & \text { Mitra Jaya }\end{array}$ & $\begin{array}{l}\text { a. Risiko sisa saldo pinjaman tidak sesuai dengan saldo } \\
\text { pinjaman menurut anggota yang berhutang. } \\
\text { b. Risiko anggota yang sudah melunasi masih terpotong gajinya. }\end{array}$ \\
\hline 2 & $\begin{array}{l}\text { Siklus } \\
\text { pembagian } \\
\text { SHU pada } \\
\text { Koperasi } \\
\text { Mitra Jaya }\end{array}$ & $\begin{array}{l}\text { Proses perhitungan dan } \\
\text { pencairan SHU pada } \\
\text { Koperasi Mitra Jaya }\end{array}$ & $\begin{array}{l}\text { a. Risiko mekanisme perhitungan besaran SHU tidak memiliki } \\
\text { dasar yang kuat/ tidak dapat dipertanggungjawabkan. } \\
\text { b. Risiko pelaporan yang tidak handal, data terkumpul baru } \\
\text { dibuatkan laporan keuangan (sistem batch) } \\
\text { c. Risiko pembuatan cek secara bulk untuk beberapa transaksi } \\
\text { sehingga sulit ditelusuri }\end{array}$ \\
\hline
\end{tabular}

Sumber: Data Diolah (2020)

Analisis Kecurangan akuntansi pada Koperasi Mitra Jaya Kelurahan Penarukan Kecamatan Buleleng dari perspektif Pressure.

Kecurangan akuntansi dapat terjadi karena adanya tekanan baik secara internal maupun eksternal. Dalam Crowe's fraud pentagon theory hal tersebut termasuk dalam pressure yaitu sebuah dorongan yang menyebabkan seseorang melakukan tindakan fraud, contohnya hutang atau tagihan yang menumpuk, gaya hidup mewah, ketergantungan narkoba, dan sebagainya (Dita, 2016). Terdapat enam jenis kondisi tekanan yang berdampak pada timbulnya fraud (Hanifa, 2015) yaitu: stabilitas keuangan, tekanan eksternal, target keuangan, debt (Hutang), likuiditas, dan tingkat kinerja

Berdasarkan rangkuman hasil wawancara dengan para pengurus Koperasi Mitra Jaya Kelurahan Penarukan Kecamatan Buleleng, kasus kecurangan akuntansi atau fraud yang dilakukan oleh oknum tertentu baik dari pengurus maupun anggota koperasi dilihat dari aspek pressure lebih dikarenakan oleh hutang atau kewajiban terhadap pihak ketiga (bank) yang tidak dapat dibayarkan sehingga memilih untuk meminjam di koperasi untuk melunasinya. Tetapi dalam pengajuan pinjaman peruntukan yang dicantumkan berbeda, misal dalam pengajuan pinjaman peruntukan dicantumkan untuk dipergunakan sebagai modal usaha. Namun, yang sebenarnya terjadi adalah dana pinjaman tersebut digunakan untuk membayar hutang yang tidak ada kaitannya dengan usahanya. Masalah lainnya adalah ketika pengurus koperasi ada yang memiliki hutang dan tidak bisa membayar dan pada saat tersebut oknum tersebut memiliki kesadaran moral yang rendah maka tekanan akibat hutang akan mendorongnya berbuat kecurangan atau fraud, misal dengan meanipulasi laporan keuangan koperasi.

Berdasarkan hasil tersebut menunjukkan bahwa pressure atau tekanan dapat menjadi faktor pendorong seseorang disini bisa pengurus koperasi maupun anggota koperasi melakukan kecurangan khususnya kecurangan akuntansi. Sehingga dapat disimpulkan bahwa pressure atau tekanan berpengaruh terhadap terjadinya kecurangan akuntansi pada Koperasi 
Mitra Jaya. Hal ini mendukung hasil penelitian dari Septriani dan Handayani (2018), Zaki (2017), dan Sariutami dan Nurbaiti (2016) menyatakan bahwa tekanan berupa tekanan eksternal dengan proksi rasio leverage berpengaruh positif terhadap kecurangan pelaporan keuangan. Berbeda dengan penelitian yang dilakukan oleh Ulfah et al. (2017) dan Annisya et al. (2016) menyatakan bahwa tekanan yang diproksikan dalam leverage tidak berpengaruh signifikan terhadap kecurangan pelaporan keuangan.

\section{Analisis kecurangan akuntansi pada Koperasi Mitra Jaya Kelurahan Penarukan Kecamatan} Buleleng dari perspektif Opportunity.

Opportunity adalah peluang/ kesempatan atau situasi dan kondisi yang ada pada setiap orang atau individu. Situasi dan kondisi tersebut memungkinkan seseorang bisa berbuat atau melakukan kegiatan yang memungkinkan terjadinya fraud. Hal ini terjadi biasanya disebabkan karena internal kontrol suatu organisasi yang lemah, kurangnya pengawasan, dan/atau penyalahgunaan wewenang. Terdapat dua kondisi peluang yang dapat memicu terjadinya fraud (Hanifa, 2015) yaitu: efektivitas pengawasan dan kualitas auditor eksternal.

Berdasarkan rangkuman hasil wawancara dengan para pengurus dan beberapa anggota Koperasi Mitra Jaya Kelurahan Penarukan Kecamatan Buleleng, indikasi terjadinya kecurangan akuntansi yang dilakukan oleh pengurus maupun anggota koperasi dengan memanfaatkan kesempatan yang ada telah terjadi pada beberapa kasus. Seperti kasus oknum bendahara sebelumnya yang melakukan penggelapan uang dengan memanfaatkan kelemahan dalam pengawasan akibat tidak berjalannya fungsi kontrol sehingga menjadi celah bagi pengurus tersebut mempergunakan dana koperasi untuk keperluan pribadi. Hal tersebut dapat dikatakan bahwa dalam aspek kecurangan atau fraud yang dilakukan oleh oknum bendahara tersebut diakibatkan oleh adanya kesempatan atau opportunity dari lemahnya pengawasan dari pihak anggota maupun pengawas koperasi yang telah dibentuk. Kemungkinan lainnya adalah karena adanya kolusi antara oknum bendahara dengan oknum tertentu sehingga kecurangan yang telah dilakukan berjalan mulus.

Menurut Priantara dalam Ulfah et al. (2017) pelaku fraud percaya bahwa aktivitas mereka tidak akan terdeteksi. Menurut American Institute of Certified Public Accountant (2002), ineffective monitoring merupakan kondisi dimana sistem pengendalian internal tidak berjalan secara efektif sehingga menimbulkan kesempatan dalam melakukan kecurangan.

Berdasarkan hasil tersebut menunjukkan bahwa opportunity atau kesempatan dapat menjadi faktor pendorong seseorang dalam hal ini pengurus koperasi maupun anggota koperasi dalam melakukan kecurangan khususnya kecurangan akuntansi. Sehingga dapat disimpulkan bahwa opportunity atau kesempatan berpengaruh terhadap terjadinya kecurangan akuntansi pada Koperasi Mitra Jaya. Hal ini mendukung hasil peneltian dari Alwi et al. (2013) dan Septriani dan Handayani (2018) menyatakan bahwa kesempatan berupa ketidakefektifan pengawasan diproksikan dengan persentase jumlah komite audit independen berpengaruh positif dan signifikan terhadap kecurangan pelaporan keuangan. Berbeda dengan penelitian yang dilakukan oleh Prasetyo (2014) menyatakan bahwa persentase jumlah komite audit independen tidak berpengaruh terhadap kecurangan pelaporan keuangan.

\section{Analisis kecurangan akuntansi pada Koperasi Mitra Jaya Kelurahan Penarukan Kecamatan Buleleng dari perspektif Rasionalisasi.}

Tuanakotta (2014) menjelaskan, rasionalisasi yaitu tindakan mencari pembenaran sebelum melakukan fraud, bukan sesudahnya. Pelaku fraud cenderung mempercayai bahwa tindakannya bukanlah tindakan yang menyalahi aturan. Keyakinan ini didukung oleh adanya keyakinan individu mengenai faktor pendukung dan/atau penghambat untuk melakukan suatu perilaku yang didasarkan pada pengalaman terdahulu maupun informasi yang dimiliki individu. Keyakinan individu ini biasa disebut perceived behavioral control. Perceived 
behavioral control didefinisikan sebagai persepsi individu mengenai kemudahan atau kesulitan untuk melakukan suatu perilaku. Perceived behavioral control ditentukan oleh kombinasi antara belief individu mengenai faktor pendukung dan/atau penghambat untuk melakukan suatu perilaku (control beliefs), dengan kekuatan perasaan individu akan setiap faktor pendukung ataupun penghambat tersebut (Taufik, 2019)

Berdasarkan rangkuman hasil wawancara dengan para pengurus dan beberapa anggota Koperasi Mitra Jaya Kelurahan Penarukan Kecamatan Buleleng, terjadinya kecurangan akuntansi di Koperasi Mitra Jaya juga diakibatkan oleh adanya tindakan pembenaran atas kecurangan yang telah dilakukan oleh pelaku. Oknum yang melakukan kecurangan tersebut meyakini bahwa tindakan fraud yang akan dilakukannya adalah benar karena alasan kepentingan atau kebutuhan yang mendesak yang nantinya uang yang diambil dari dana koperasi tersebut akan dikembalikan jika sudah memiliki uang. Hal ini menimbulkan kondisi "gali lubang tutup lubang". Artinya oknum tersebut meminjam uang koperasi untuk kepentingan pribadinya yang mendesak dan ketika sudah memiliki uang untuk mengembalikan, oknum tersebut akan mengembalikan uang koperasi yang telah dipijamnya tersebut. Begitu seterusnya hingga oknum tersebut merasa bahwa uang tersebut tidak perlu dikembalikan lagi. Selain itu, memanfaatkan aset yang dimiliki oleh koperasi untuk kepentingan pribadi seperti menggunakan kendaraan kantor untuk kepentingan pribadi dengan niat awal bahwa perilaku tersebut merupakan perilaku yang benar dan sah-sah saja. Hal ini menunjukkan bahwa perceived behavioral control oknum koperasi yang melakukan fraud rendah artinya, oknum tersebut memiliki kontrol perilaku yang rendah sehingga memiliki keyakinan bahwa banyak faktor pendukung untuk melakukan fraud dan sedikit faktor penghambat untuk melakukan fraud maka oknum akan memiliki persepsi mudah untuk melakukan fraud sehingga perilaku fraud cenderung akan meningkat.

Berdasarkan hal tersebut dapat dikatakan bahwa rasionalisasi dapat mengakibatkan terjadinya kecurangan akuntansi pada Koperasi Mitra Jaya baik dilakukan oleh anggota maupun pengurus koperasi. Albrecht et al. (2011) mengemukakan bahwa rasionalisasi yang sering terjadi ketika melakukan fraud antara lain:1. Aset itu sebenarnya milik saya (perpetrator's Fraud), 2. Saya hanya meminjam dan akan membayarnya kembali, 3. Tidak ada pihak yang dirugikan, 4. Ini dilakukan untuk sesuatu yang mendesak, 5. Kami akan memperbaiki pembukuan setelah masalah keuangan ini selesai, 6. Saya rela mengorbankan reputasi dan integritas saya asal hal itu dapat meningkatkan standar hidup saya. Para pelaku fraud menganggap perilaku tersebut etis karena merupakan haknya yang telah berjasa banyak untuk perusahaan (Priantara dalam Ulfah et al. 2017).

Hal ini mendukung hasil peneltian dari Siddiq et al. (2017) dan Abdullahi dan Mansor (2018) bahwa rasionalisasi yang diproksikan dengan perubahan auditor berpengaruh positif dan signifikan terhadap kecurangan pelaporan keuangan. Berbeda dengan penelitian yang dilakukan oleh Kusumaningrum dan Murtanto (2016) dan Sariutami dan Nurbaiti (2016) menyatakan bahwa rasionalisasi yang diproksikan oleh perubahan auditor tidak berpengaruh terhadap kecurangan pelaporan keuangan.

Analisis kecurangan akuntansi pada Koperasi Mitra Jaya Kelurahan Penarukan Kecamatan Buleleng dari perspektif Competency.

Individual capability adalah sifat dan kemampuan pribadi seseorang yang mempunyai peranan besar yang memungkinkan melakukan suatu tindak kecurangan. Competence merupakan perkembangan dari elemen opportunity yaitu kemampuan individu untuk mengesampingkan internal kontrol dan mengontrolnya sesuai dengan kedudukan sosialnya untuk kepentingan pribadinya. Competence adalah keahlian karyawan untuk mengabaikan kontrol internal, mengembangkan strategi penyembunyian, dan mengamati kondisi sosial untuk memenuhi kepentingan pribadinya (Crowe, 2011) 
Berdasarkan rangkuman hasil wawancara dengan para pengurus maupun beberapa anggota Koperasi Mitra Jaya Kelurahan Penarukan Kecamatan Buleleng, kasus kecurangan akuntansi karena oknum tersebut memiliki kemampuan dan pengetahuan untuk mampu melakukan kecurangan sehingga tidak diketahui oleh pihak pengawas koperasi. Hal ini bisa terjadi karena oknum merasa bahwa dirinya mampu mengesampingkan internal kontrol dan mengontrolnya sesuai dengan kedudukan sosialnya demi kepentingan pribadinya. Tidak adanya transparansi dan cenderung menyembunyikan permasalahan dengan tidak mengandalkan pengawasan dari pengurus dan pengawas mengakibatkan kecurangan akuntansi yang dilakukan oknum pengurus maupun anggota tidak dapat dideteksi sejak awal sehingga berdampak pada keberlangsungan koperasi.

Berdasarkan hal tersebut dapat disimpulkan bahwa kecurangan atau fraud yang dilakukan oleh oknum pengurus maupun anggota Koperasi Mitra Jaya didorong oleh faktor competency yaitu kemampuan individu untuk mengesampingkan internal kontrol dan mengontrolnya sesuai dengan kedudukan sosialnya untuk kepentingan pribadinya.

Berdasarkan hasil tersebut menunjukkan bahwa competence/capability dapat menjadi faktor pendorong seseorang melakukan kecurangan khususnya kecurangan akuntansi sehingga dapat disimpulkan bahwa competence/capability berpengaruh terhadap terjadinya kecurangan akuntansi pada Koperasi Mitra Jaya. Hal ini mendukung hasil penelitian dari Devy et al. (2017) dan Manurung dan Hardika (2015) menyatakan bahwa kemampuan yang diproksikan dengan perubahan susunan direksi perusahaan berpengaruh positif terhadap kecurangan pelaporan keuangan. Berbeda dengan penelitian yang dilakukan oleh Harahap et al. (2017) dan Annisya et al. (2016) menyatakan bahwa perubahan susunan direksi tidak berpengaruh terhadap kecurangan pelaporan keuangan.

Analisis kecurangan akuntansi pada Koperasi Mitra Jaya Kelurahan Penarukan Kecamatan Buleleng dari perspektif Arrogance.

Arogansi merupakan sifat kurangnya hati nurani sebagai sikap superioritas atau adanya sifat congkak pada seseorang yang percaya bahwa pengendalian internal tidak dapat diberlakukan secara pribadi (Aprilia, 2017). Crowe (2011) menjelaskan bahwa arogansi merupakan sifat superioritas atas hak yang dimiliki dan merasa bahwa pengendalian internal dan kebijakan perusahaan tidak berlaku untuk dirinya. Kecurangan akuntansi pada Koperasi Mitra Jaya dapat terjadi akibat adanya arogansi dari pengurus maupun anggota. Contoh kasus yang telah terjadi yang mana oknum bendahara pada Koperasi Mitra Jaya melakukan tindak kecurangan atau fraud dengan memanipulasi pencatatan dan pelaporan keuangan koperasi. Manipulasi tersebut dilakukan karena pelaku merasa superior, merasa bahwa pengendalian internal dan kebijakan koperasi tidak berlaku untuk dirinya. Hal ini juga didukung karena kondisi koperasi saat itu didominasi oleh para pengurus saja tanpa adanya kontrol dari pengawas maupun anggota lainnya sehingga memberikan celah pada oknum tersebut untuk melakukan kecurangan.

Berdasarkan rangkuman hasil wawancara dengan para pengurus maupun beberapa anggota Koperasi Mitra Jaya Kelurahan Penarukan Kecamatan Buleleng, ada beberapa kasus kecurangan akuntansi akibat adanya sikap superioritas dan keserakahan dalam sebagian diri anggota maupun pengurus yang menganggap bahwa kebijakan dan prosedur perusahaan sederhananya tidak berlaku secara pribadi. Hal ini memang belum terdeteksi secara pasti, namun pihak koperasi khususnya pengawas masih terus melakukan control dan pemeriksaan guna mencari bukti yang kuat.

Oknum yang melakukan kecurangan atas dasar sifat arogan menyebabkan dirinya merasa bahwa tindakan yang dilakukan akan dapat di antisipasi dan di anggap sebagai suatu hal yang biasa tanpa adanya kesadaran bahwa akibat dari perbuatan tersebut mengandung resiko baik resiko sosial maupun resiko hukum. 
Berdasarkan hal tersebut dapat dikatakan bahwa kecurangan atau fraud yang dilakukan oleh oknum pengurus atau anggota Koperasi Mitra Jaya dapat diakibatkan oleh sifat arogan atau arrogance. Hal ini mendukung hasil peneltian dari Tessa dan Harto (2016) dan Arisandi dan Verawaty (2017) menyatakan bahwa arogansi yang diproksikan dengan frequent number of CEO's picture berpengaruh positif dan signifikan terhadap kecurangan pelaporan keuangan. Berbeda dengan penelitian yang dilakukan oleh Aprilia (2017) dan Ulfah et al. (2017) menyatakan bahwa frekuensi kemunculan gambar CEO tidak berpengaruh terhadap kecurangan pelaporan keuangan.

\section{Simpulan dan Saran}

Berdasarkan hasil penelitian dan pembahasan maka simpulan dari penelitian ini adalah: 1) ada Kecurangan atau fraud yang dilakukan oleh oknum pengurus maupun anggota Koperasi Mitra Jaya diakibatkan oleh pressure atau tekanan baik karena adanya hutang, gaya hidup mewah, maupun tekanan ekonomi sehingga berpengaruh terhadap keberlangsungan koperasi. 2) Kecurangan atau fraud yang dilakukan oleh oknum pengurus maupun anggota Koperasi Mitra Jaya diakibatkan oleh opportunity atau kesempatan baik karena situasi dan kondisi yang memungkinkan seseorang bisa melakukan kecurangan. Biasanya disebabkan karena internal kontrol suatu organisasi yang lemah, kurangnya pengawasan, dan/atau penyalahgunaan wewenang. 3) Kecurangan atau fraud yang dilakukan oleh oknum pengurus maupun anggota Koperasi Mitra Jaya yang diakibatkan oleh rasionalisasi yaitu tindakan yang mencari alasan pembenaran terhadap tindakan yang salah karena merasa dirinya terjebak dalam suatu keadaan yang buruk. 4) Kecurangan atau fraud yang dilakukan oleh oleh oknum pengurus maupun anggota Koperasi Mitra Jaya diakibatkan oleh competency yaitu kecurangan yang dilakukan karena oknum tersebut memiliki kemampuan untuk mengesampingkan internal kontrol dan mengontrolnya sesuai dengan kedudukan sosialnya untuk kepentingan pribadinya. 5) Kecurangan atau fraud yang dilakukan oleh oleh oknum pengurus maupun anggota Koperasi Mitra Jaya diakibatkan oleh arrogance lebih menekankan pada sikap superioritas dan keserakahan dalam sebagian diri oknum pengurus maupun anggota koperasi yang menganggap bahwa kebijakan dan prosedur perusahaan sederhananya tidak berlaku secara pribadi.

Berdasarkan simpulan di atas, dapat dikemukakan saran-saran sebagai berikut: 1) Bagi Pihak Koperasi Mitra Jaya diharapkan untuk lebih meningkatkan kontrol internal, pelaporan keuangan serta meningkatkan kapabilitas dan integritas pengurus dan anggota sehingga dapat terhidar maupun dapat meminimalisir terjadinya fraud. 2) bagi peneliti selanjutnya, diharapkan dapat menganalisis permasalahan fraud dengan cara pandang yang berbeda seperti analisis dampak jangka panjang maupun jangka pendek dari adanya fraud serta menambah variabel penelitian. 3) Bagi Pemerintah disarankan untuk lebih meningkatkan pengawasan terhadap koperasi-koperasi yang berkembang dimasyarakat agar tidak merugikan masyarakat.

\section{Daftar Pustaka}

Chandra, D. P. 2015. Determinan terjadinya kecenderungan kecurangan akuntansi (fraud) pada Dinas Pemerintah Se Kabupaten Grobogan. Accounting Auditing Journal 4 (3)

Devi, N. S. 2011. Pengaruh kompensasi dan sistem pengendalian intern terhadap kecenderungan kecurangan akuntansi (studi empiris pada kantor cabang bank pemerintah dan swasta di kota padang). Jurnal auditing UNP Padang.

Iqbal Muhammad. 2010. Pengaruh Tindakan Pencegahan, Pendeteksian dan Audit Investigatif Terhadap Upaya Meminimalisasi Kecurangan dalam Laporan Keuangan. 
Skripsi. Jurusan Akuntansi. Universitas Islam Negeri Syarif Hidayatullah Jakarta.

Kusumastuti, N. R. 2012. Analisis faktor-faktor yang berpengaruh terhadap kecenderungan kecurangan akuntansi dan perilaku tidak etis sebagai variabel intervening. Jurnal Akuntansi Auditing UNDIP.

Norbarani, L. 2012. Pendeteksian kecurangan laporan keuangan dengan analisis fraud triangle yang diadopsidalam sas no.99. Journal Managerial Accounting Semarang :Fakultas Ekonomi UNDIP

Pamungkas, I. D. (2014). Pengaruh religiusitas dan rasionalisasi dalam mencegah dan mendeteksi kecenderungan kecurangan akuntansi. Jurnal Ekonomi dan bisnis volume 15 nomor 2 ISSIN1693-0008

Rahmawati A Peni. 2012. Analisis Pengaruh Faktor Internal dan Moralitas Manajemen Terhadap Kecenderungan Kecurangan Akuntansi (Studi Pada Dinas Pengelola Keuangan dan Aset Daerah Kota Semarang). Skripsi. Jurusan Akuntansi, Universitas Diponegoro.

Ratri K Nur. 2012. Analisis Faktor-faktor yang Berpengaruh Terhadap Kecenderungan Kecurangan Akuntansi dengan Perilaku Tidak Etis Sebagai Variabel Intervening. Skripsi. Jurusan Akuntansi. Universitas Diponegoro.

Tuanakotta, Theodorus M. 2014. Audit Forensik dan Audit Investigatif. Jakarta: Fakultas Ekonomi Universitas Indonesia.

Thoyibatun, Siti. 2009. Faktor-faktor yang berpengaruh terhadap perilaku tidak etis dan kecenderungan kecurangan akuntansi serta akibatnya terhadap kinerja organisasi. Jurnal Ekonomi dan Keuangan volume 16 nomor 2:245260.

Wilopo. 2006. Analisis faktor-faktor yang berpengaruh terhadap kecenderungan kecurangan akuntansi studi pada perusahaan publik dan perusahaan badan usaha milik negara. SNA IX : Padang 